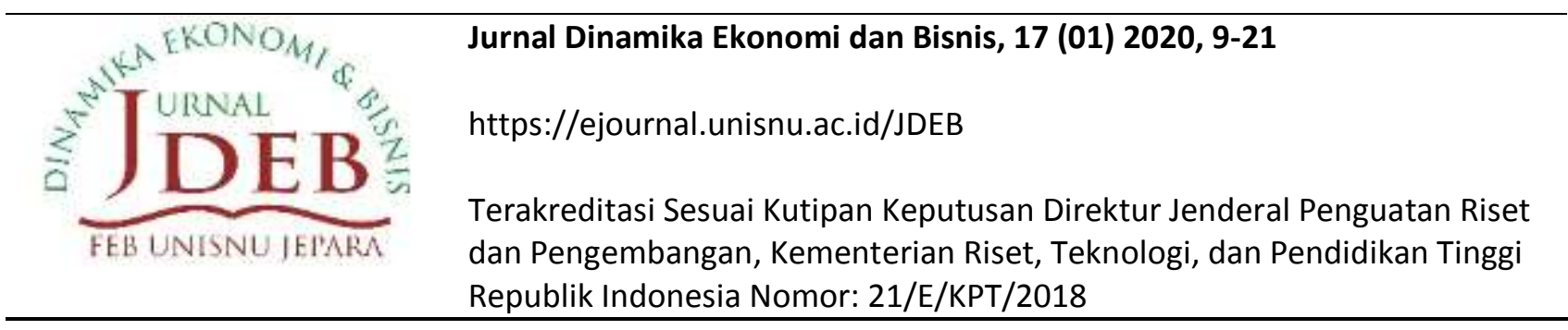

\title{
Analisis Pengaruh Faktor-faktor Demografi Terhadap Kepatuhan Perpajakan
}

\author{
Sri Mulyani', Nita Andriyani Budiman²), Riyadlus Mei Sakinah ${ }^{3)}$ \\ Fakultas Ekonomi dan Bisnis, Universitas Muria Kudus ${ }^{1,2)}$ \\ Email: s.mulyani@umk.ac.id ${ }^{1)}$ nitandriyani@gmail.com ${ }^{2)}$ riyadlus@umk.ac.id ${ }^{3)}$
}

\begin{abstract}
This study aims to determine how the influence of demographic factors on tax compliance. The data collection is done by distributing questionnaires and the sample size of 100 respondents. This research was done KPP Pratama Kudus. Data were analyzed using Chi-Square test. Demographic factors examined included gender, age, education level, marital status, occupation, and income levels. The results showed that the respondent men and women have the same tax compliance while for age, education level, occupation, and income levels have different levels of tax compliance.
\end{abstract}

Keywords: Tax compliance, gender, age, education level, occupation, and income levels

\section{Abstrak}

Penelitian ini bertujuan untuk mengetahui bagaimana pengaruh faktor-faktor demografi terhadap kepatuhan perpajakan. Pengumpulan data dilakukan dengan cara menyebarkan kuesioner dan jumlah sampel sebanyak 100 responden. Penelitian ini dilakukan di KPP Pratama Kudus. Data dianalisis dengan menggunakan uji Chi-Square. Faktor demografi yang diteliti meliputi jenis kelamin, umur, tingkat pendidikan, status pernikahan, jenis pekerjaan, dan tingkat penghasilan. Hasil penelitian ini menunjukkan bahwa responden laki-laki dan perempuan mempunyai kepatuhan perpajakan yang sama sedangkan untuk umur, tingkat pendidikan, jenis pekerjaan, dan tingkat penghasilan memiliki tingkat kepatuhan pajak yang berbeda.

Kata Kunci: Kepatuhan perpajakan, jenis kelamin, umur, tingkat pendidikan, jenis pekerjaan, dan tingkat penghasilan

Siatasi: Mulyani, S., Budiman, N. A., Sakinah, R. M., (2020). Analisis Pengaruh Faktor-faktor Demografi Terhadap Kepatuhan Perpajakan, Jurnal Dinamika Ekonomi dan Bisnis, 17 (01) 2020, 9-21 


\section{PENDAHULUAN}

Indonesia merupakan negara berkembang yang sedang giat melakukan pembangunan di segala bidang. Baik bidang ekonomi, sosial, kesehatan, dan pendidikan. Untuk melakukan pembangunan negara, pemerintah perlu memikirkan kembali langkah apa yang dapat ditempuh untuk mengumpulkan dana, sehingga tidak lagi tergantung dengan dana dari pihak ketiga. Salah satu langkah yang dapat ditempuh untuk mengumpulkan dana pembangunan negara adalah dengan meningkatkan sumber penerimaan negara sehingga dalam membiayai pembangunan dapat dilakukan dengan mandiri. Sumber penerimaan negara bisa didapatkan dari pihak internal yaitu warga negara Indonesia dan pihak eksternal misalnya warga negara asing atau para turis luar negeri yang sedang berlibur di Indonesia.

Pajak digunakan sebagai salah satu usaha yang digunakan oleh pemerintah untuk mewujudkan kemandirian suatu bangsa atau negara dalam pembiayaan pembangunan yang berguna bagi kepentingan bersama. Pajak merupakan sumber utama penerimaan negara. Tanpa pajak sebagian besar kegiatan negara sulit untuk dilaksanakan. Pembangunan jalanjalan, jembatan, sekolah, rumah sakit atau Puskesmas, kantor polisi, dan fasilitas umum lainnya dibiayai menggunakan uang yang berasal dari pajak.

Besarnya penerimaan pajak tergantung pada kepatuhan wajib pajak. Tingkat kepatuhan wajib pajak di Indonesia masih sangatlah rendah. Kesadaran masyarakat akan kewajibannya dalam membayar pajak akan mempengaruhi tingkat kepatuhan. Kesadaran masyarakat yang tinggi akan mendorong semakin banyak masyarakat memenuhi kewajibannya untuk mendaftarkan diri sebagai wajib pajak, melaporkan dan membayar pajaknya dengan benar sebagai wujud tanggungjawab berbangsa dan bernegara.

Menurut Mardiasmo (2011) wajib pajak adalah orang pribadi atau badan, meliputi pembayaran pajak, pemotong pajak, dan pemungut pajak, yang mempunyai hak dan kewajiban perpajakan sesuai dengan ketentuan peraturan perundang-undangan perpajakan. Subjek pajak yang menjadi responden dalam penelitian ini adalah wajib pajak orang pribadi.

Penelitian yang dilakukan oleh Pasaribu dan Tjen (2015) mengungkapkan bahwa tidak ada perbedaan kepatuhan perpajakan antara responden berjenis kelamin laki-laki maupun responden berjenis kelamin perempuan. Hasil penelitian ini sama dengan penelitian yang dilakukan Kurniati dan Fevriera (2011) dan Al-Mamun et al (2014).

Penelitian yang dilakukan oleh Pasaribu dan Tjen (2015) dan Al-Mamun et al (2014) mengungkapkan bahwa umur wajib pajak tidak ada perbedaan kepatuhan perpajakan, sedangkan umur wajib pajak berpengaruh positif terhadap kepatuhan perpajakan terdapat dalam penelitian Kurniati dan Fevriera (2011). Penelitian yang dilakukan oleh Pasaribu dan Tjen (2015) mengungkapkan bahwa tingkat pendidikan wajib pajak terdapat perbedaan kepatuhan perpajakan, sedangkan tingkat pendidikan berpengaruh positif terhadap kepatuhan perpajakan terdapat dalam penelitian Al-Mamun et al (2014) dan Kurniati dan Fevriera (2011).

Penelitian yang dilakukan oleh Pasaribu dan Tjen (2015) mengungkapkan bahwa jenis pekerjaan wajib pajak terdapat perbedaan atau berpengaruh terhadap kepatuhan perpajakan, dan sebaliknya jenis pekerjaan wajib pajak tidak ada perbedaan kepatuhan perpajakan terdapat dalam penelitian Kurniati dan Fevriera (2011). Penelitian yang dilakukan oleh 
Pasaribu dan Tjen (2015) mengungkapkan bahwa tingkat penghasilan wajib terdapat perbedaan kepatuhan perpajakan, sedangkan tingkat penghasilan wajib pajak berpengaruh negatif terhadap kepatuhan perpajakan terdapat dalam penelitian Kurniati dan Fevriera (2011).

Penelitian ini merupakan pengembangan dari penelitian yang telah dilakukan oleh Pasaribu dan Tjen (2015). Adapun perbedaan dari penelitian Pasaribu dan Tjen (2015) adalah penelitian ini hanya dilakukan di KPP Pratama Kudus, sedangkan pada penelitian Pasaribu dan Tjen (2015) dilakukan dengan menyebarkan kuesioner secara online dengan menggunakan google docs pada tahun 2014. Sampel dalam penelitian ini adalah wajib pajak orang pribadi yang terdaftar di KPP Pratama Kudus yang datang ke KPP Pratama Kudus. Sedangkan sampel yang digunakan dalam penelitian Pasaribu dan Tjen (2015) adalah responden yang telah melakukan pengisian kuesioner. Berdasarkan latar belakang di atas, maka judul penelitian ini adalah "Pengaruh Faktor-Faktor Demografi terhadap Kepatuhan Perpajakan".

\section{KAJIAN PUSTAKA}

\section{Theory of Planned Behavior}

Kajian mengenai faktor-faktor yang mempengaruhi perilaku kepatuhan pajak salah satunya adalah melalui Theory of Planned Behavior (Ajzen, 1991). Theory of Planned Behavior atau yang disebut dengan Teori Perilaku Terencana didasarkan pada asumsi bahwa manusia adalah makhluk yang rasional dan menggunakan informasi-informasi yang mungkin baginya, secara sistematis. Orang memikirkan implikasi dari tindakan mereka sebelum mereka memutuskan untuk melakukan atau tidak melakukan perilaku-perilaku tertentu (Achmat, 2010) dalam Halimah (2012). Inti dari teori ini mencakup 3 hal (Ajzen, 1991) yaitu:

1. Behavioral belief

Keyakinan tentang kemungkinan hasil dan evaluasi dari perilaku tersebut.

2. Normative belief

Keyakinan tentang norma yang diharapkan dan motivasi untuk memenuhi harapan tersebut.

3. Control belief

Keyakinan tentang adanya faktor yang dapat mendukung atau menghalangi perilaku dan kesadaran akan kekuatan faktor tersebut.

Dikaitkan dengan penelitian ini, theory of planned behavior relevan untuk menjelaskan perilaku wajib pajak dalam memenuhi kewajiban perpajakannya, sebelum individu melakukan sesuatu, individu tersebut akan memiliki keyakinan-keyakinan mengenai hasil yang akan diperoleh dari perilakunya tersebut. Keyakinan-keyakinan itulah yang berhubungan dengan behavioral belief. Kemudian individu tersebut akan memutuskan bahwa akan melakukannya atau tidak melakukannya. Jika hasil yang diperoleh dari perilakunya tersebut menguntungkan, maka individu tersebut akan melakukannya, demikian sebaliknya. Hal tersebut berkaitan dengan kepatuhan perpajakan. Wajib pajak yang patuh pajak akan memiliki keyakinan mengenai pentingnya membayar pajak untuk membantu menyelenggarakan pembangunan negara (behavioral beliefs). 
Pada saat melakukan suatu perilaku, individu akan memiliki keyakinan tentang harapan normatif dari orang lain dan motivasi untuk memenuhi harapan tersebut (normative beliefs). Hal ini berkaitan dengan pelayanan pajak, dimana dengan adanya pelayanan yang baik dari petugas pajak, sistem perpajakan yang efisien dan efektif, serta penyuluhanpenyuluhan pajak yang memberikan motivasi kepada wajib pajak agar taat pajak, akan membuat wajib pajak memiliki keyakinan atau memilih perilaku taat pajak. Dalam penelitian ini berkaitan dengan variabel jenis kelamin, umur, tingkat pendidikan, status pernikahan, jenis pekerjaan, tingkat penghasilan wajib pajak.

Control beliefs berkaitan dengan sanksi pajak. Control beliefs adalah keyakinan tentang adanya faktor yang dapat mendukung atau menghalangi perilaku dan kesadaran akan kekuatan faktor tersebut. Sanksi pajak dibuat adalah untuk mendukung agar wajib pajak mematuhi peraturan perpajakan. Kepatuhan perpajakan akan ditentukan berdasarkan persepsi wajib pajak tentang seberapa kuat sanksi pajak mampu mendukung perilaku wajib pajak untuk taat pajak.

\section{Kepatuhan Perpajakan}

Pengertian kepatuhan menurut kamus besar bahasa Indonesia adalah tunduk atau patuh dalam ajaran atau aturan. Sedangkan menurut Nurmantu (2005) kepatuhan perpajakan didefinisikan sebagai suatu keadaan dimana Wajib Pajak (WP) memenuhi semua kewajiban perpajakan dan melaksanakan hak perpajakannya.

Menurut Budiman (2018) terdapat dua macam kepatuhan yakni kepatuhan formal dan kepatuhan materiil. Kepatuhan formal adalah suatu keadaan di mana WP memenuhi kewajiban perpajakan secara formal sesuai dengan ketentuan formal dalam undang-undang perpajakan. Kepatuhan materiil adalah suatu keadaan di mana WP secara substantif memenuhi semua ketentuan materiil perpajakan yakni sesuai isi dan jiwa undang-undang perpajakan (Nurmantu, 2005). Bagaimana pemerintah berupaya meningkatkan kepatuhan perpajakan telah menjadi ketertarikan teoritis dan peneliti (Gosh dan Grain, 1996 dalam Cahyonowati, 2011) jika membahas kepatuhan perpajakan WP orang pribadi maka tentunya kita harus menganalisis dalam konteks keperilakuan karena WP orang pribadi merupakan individu yang unik dengan sifat-sifat dasar seperti rasionalitas, memaksimumkan utilitas, dan menghindari risiko (Hanno dan Violette, 1996 dalam Cahyonowati, 2011).

\section{Demografi}

Demografi (demography) dari segi kata merupakan istilah yang berasal dari dua kata Yunani, yaitu demos yang berarti rakyat atau penduduk dan grafein yang berarti menggambar atau menulis. Oleh karena itu, demografi dapat diartikan sebagai tulisan atau gambaran tentang penduduk (Adioetomo dan Samosir, 2011). Ilmu demografi merupakan suatu alat untuk mempelajari perubahan-perubahan kependudukan dengan memanfaatkan data dan statistik kependudukan serta perhitungan-perhitungan secara matematis dan statistik dari data penduduk terutama mengenai perubahan jumlah, persebaran, dan komposisi atau strukturnya (Adioetomo dan Samosir, 2011). 


\section{Jenis Kelamin Wajib Pajak}

Pengertian jenis kelamin (seks) menurut Hungu (2007) adalah perbedaan antara perempuan dan laki-laki secara biologis sejak seseorang lahir. Seks berkaitan dengan tubuh laki-laki dan perempuan, dimana laki-laki memproduksikan sperma, sementara perempuan menghasilkan sel telur dan secara biologis mampu untuk menstruasi, hamil, dan menyusui. Perbedaan biologis dan fungsi biologis laki-laki dan perempuan tidak dapat dipertukarkan diantara keduanya.

Dalam Theory of Planned Behavior (TPB), jenis kelamin diyakini bisa mempengaruhi tingkat kepatuhan perpajakan karena memiliki keyakinan tentang kemungkinan hasil bahwa perempuan memiliki tingkat kepatuhan lebih tinggi dibandingkan dengan laki-laki. Perbedaan jenis kelamin mempengaruhi kepatuhan perpajakan, kenyataannya wanita lebih peka dan patuh terhadap peraturan perpajakan yang berlaku pada saat ini.

$\mathrm{H}_{1}$ : Jenis kelamin wajib pajak berpengaruh terhadap kepatuhan perpajakan.

\section{Umur Wajib Pajak}

Kamus Besar Bahasa Indonesia Pusat Bahasa, umur berarti lama waktu hidup atau ada (sejak dilahirkan atau diadakan). Umur dapat digolongkan ke dalam usia produktif dan usia yang tidak produktif. Menurut Kamus Besar Bahasa Indonesia seseorang dikatakan pada usia produktif ketika seseorang masih mampu bekerja dan menghasilkan sesuatu.

Dalam Theory of Planned Behavior (TPB), umur diyakini bisa mempengaruhi tingkat kepatuhan perpajakan karena keyakinan tentang kemungkinan hasil bahwa pada wajib pajak yang berumur lebih muda memiliki tingkat kepatuhan lebih tinggi dibandingkan dengan wajib pajak yang berumur lebih tua. Umur wajib pajak mempengaruhi kepatuhan perpajakan, kenyataannya orang yang umurnya lebih muda lebih patuh terhadap peraturan perpajakan yang berlaku pada saat ini dibandingkan dengan orang yang berumur lebih tua.

$\mathrm{H}_{2}$ : Umur wajib pajak berpengaruh terhadap kepatuhan perpajakan.

\section{Tingkat Pendidikan Wajib Pajak}

Pendidikan pada hakikatnya adalah proses pematangan kualitas hidup. Melalui proses tersebut diharapkan manusia dapat memahami apa arti dan hakikat hidup, serta untuk apa dan bagaimana menjalankan tugas hidup dan kehidupan secara benar (Mulyasana, 2012). Fungsi pendidikan adalah mengembangkan kemampuan dan membentuk watak serta peradaban bangsa yang bermartabat.

Dalam Theory of Planned Behavior (TPB), tingkat pendidikan diyakini bisa mempengaruhi tingkat kepatuhan perpajakan karena keyakinan tentang kemungkinan hasil bahwa pada wajib pajak yang berpendidikan tinggi memiliki tingkat kepatuhan lebih tinggi dibandingkan dengan wajib pajak yang tingkat pendidikannya lebih rendah. Semakin tinggi tingkat pendidikan seseorang maka tingkat pengetahuan mengenai peraturan perpajakan akan semakin luas dan lebih luas memahami manfaat membayar pajak dibandingkan seseorang yang berpendidikan lebih rendah.

$\mathrm{H}_{3}$ : Tingkat pendidikan wajib pajak berpengaruh terhadap kepatuhan perpajakan. 


\section{Jenis Pekerjaan Wajib Pajak}

Jenis pekerjaan adalah macam pekerjaan yang sedang dilakukan oleh orang-orang yang termasuk golongan bekerja (Adioetomo dan Samosir, 2011). Perbedaan pengenaan pajak atas penghasilan yang diterima oleh karyawan dengan wiraswasta dapat mempengaruhi kepatuhan perpajakan.

Dalam Theory of Planned Behavior (TPB), jenis pekerjaan diyakini bisa mempengaruhi tingkat kepatuhan perpajakan karena keyakinan tentang kemungkinan hasil bahwa pada wajib pajak yang bekerja di suatu perusahaan sebagai karyawan memiliki tingkat kepatuhan lebih tinggi dibandingkan dengan wajib pajak yang pekerjaannya sebagai pengusaha atau wiraswasta. Wiraswasta memiliki lebih banyak kesempatan untuk menghindari pajak daripada wajib pajak yang atas penghasilannya telah dipotong pajak oleh pemberi kerja.

$\mathrm{H}_{4}$ : Jenis pekerjaan wajib pajak berpengaruh terhadap kepatuhan perpajakan.

\section{Tingkat Penghasilan Wajib Pajak}

Penghasilan menurut Mardiasmo (2009) dalam Kurniati dan Fevriera (2011) adalah setiap tambahan kemampuan ekonomis yang diterima atau diperoleh wajib pajak, baik yang berasal dari Indonesia maupun dari luar Indonesia, yang dapat dipakai untuk konsumsi atau untuk menambah kekayaan wajib pajak yang bersangkutan, dengan nama dan bentuk apapun. Dalam Theory of Planned Behavior (TPB), tingkat penghasilan diyakini bisa mempengaruhi tingkat kepatuhan perpajakan karena keyakinan tentang kemungkinan hasil bahwa pada wajib pajak yang tingkat penghasilannya rendah memiliki tingkat kepatuhan lebih tinggi dibandingkan dengan wajib pajak yang tingkat penghasilannya lebih tinggi.

Hal ini disebabkan adanya ancaman sanksi finansial akan dirasa lebih memberatkan bagi kelompok wajib pajak berpendapatan rendah sehingga mereka akan lebih terdorong untuk patuh dalam membayar pajak. Artinya semakin tinggi pendapatan wajib pajak, maka akan semakin kecil peluang mereka terhadap kepatuhan perpajakan.

$\mathrm{H}_{5}$ : Tingkat penghasilan wajib pajak berpengaruh terhadap kepatuhan perpajakan. 


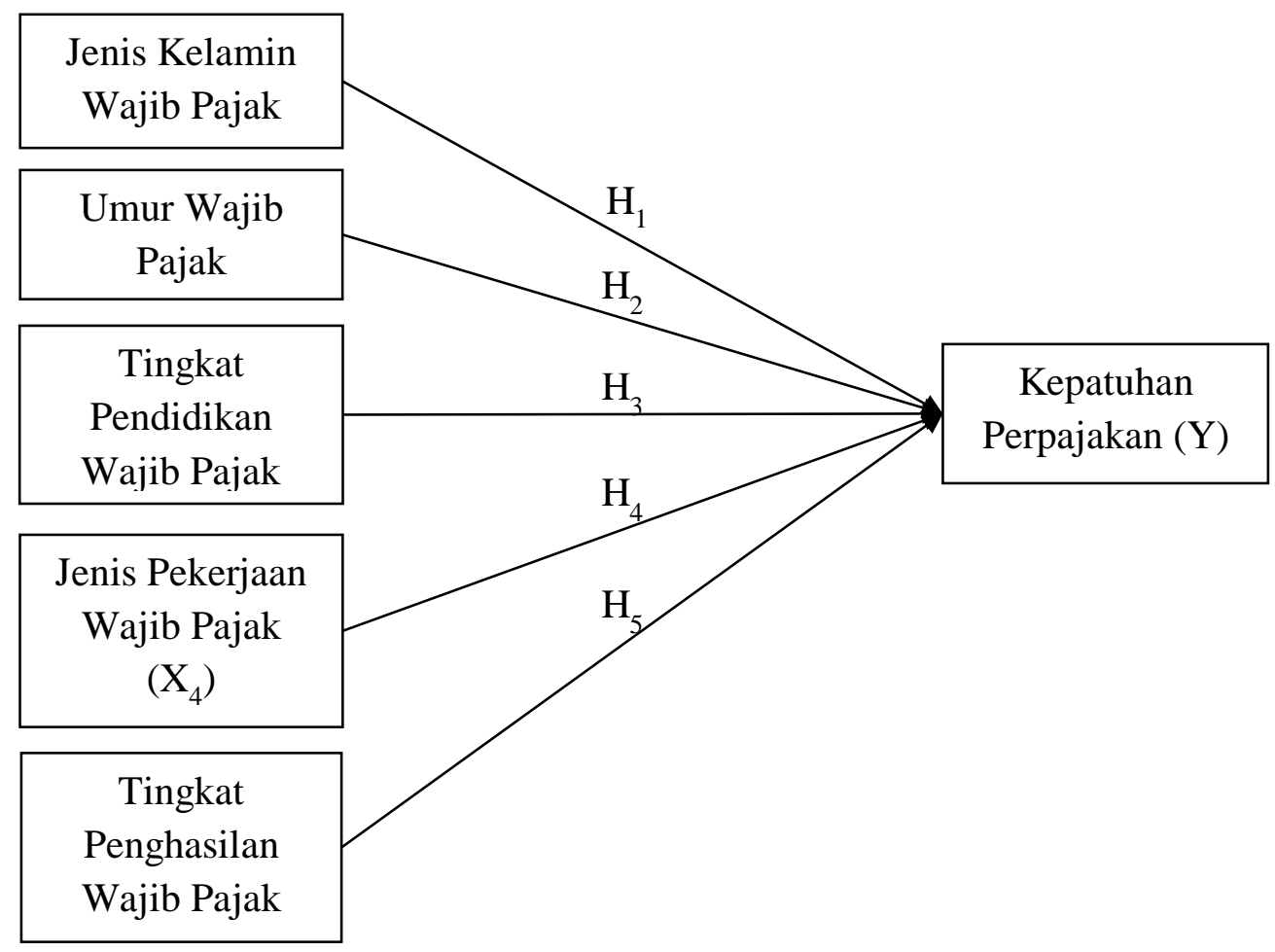

\section{Gambar 1. Kerangka Pemikiran Teoritis}

\section{METODE PENELITIAN}

Obyek dalam penelitian ini adalah Wajib Pajak Orang Pribadi (WPOP) yang terdaftar di Kantor Pelayanan Pajak Pratama Kudus yang berjumlah 63.929. Sampel yang digunakan adalah WPOP yang datang ke KPP Pratama Kudus, dengan perhitungan Slovin didapatkan hasil sebanyak 100 responden. Pengumpulan data dengan penyebaran kuesioner. Penelitian ini menggunakan uji analisis deskriptif, uji instrument, dan uji hipotesis.

\section{HASIL DAN PEMBAHASAN}

\section{Uji Validitas}

Uji validitas digunakan untuk mengukur apakah suatu kuesioner sah atau tidak. Validitas akan mengukur apakah pertanyaan dalam kuesioner yang sudah dibuat betul-betul dapat mengukur apa yang hendak diukur. Uji validitas dalam penelitian menggunakan korelasi product moment Pearson. Apabila korelasi Pearson antara butir pernyataan dengan skor total memiliki tingkat signifikansi $<0,05$ maka terjadi korelasi yang kuat. Hal ini menandakan bahwa data tersebut valid. Berikut hasil uji validitas terhadap data penelitian. 
Tabel 1. Tabel Uji Validitas

\begin{tabular}{cccc}
\hline $\begin{array}{c}\text { Variabel } \\
\text { Kepatuhan Perpajakan }\end{array}$ & R tabel & R hitung & Keterangan \\
\hline Y1 & 0,1654 & 0,319 & Valid \\
Y2 & 0,1654 & 0,498 & Valid \\
Y3 & 0,1654 & 0,533 & Valid \\
Y4 & 0,1654 & 0,570 & Valid \\
Y5 & 0,1654 & 0,438 & Valid \\
Y6 & 0,1654 & 0,458 & Valid \\
Y7 & 0,1654 & 0,490 & Valid \\
Y8 & 0,1654 & 0,599 & Valid \\
Y9 & 0,1654 & 0,546 & Valid \\
Y10 & 0,1654 & 0,618 & Valid \\
Y11 & 0,1654 & 0,550 & Valid \\
Y12 & 0,1654 & 0,385 & Valid \\
Y13 & 0,1654 & 0,247 & Valid
\end{tabular}

Sumber: Data primer diolah, 2019

Dari hasil uji validitas menunjukkan bahwa nilai pearson correlation lebih besar dari nilai $r$ tabel untuk $n=100$ yaitu 0,1654 . Dengan demikian, item-item pada masing-masing konsep variabel tersebut layak digunakan sebagai alat ukur dalam pengujian statistik.

\section{Uji Reliabilitas}

Uji reliabilitas digunakan untuk mengetahui keajekan atau konsistensi alat ukur yang biasanya menggunakan kuesioner untuk dapat digunakan lagi untuk penelitian yang sama. Pengujian reliabilitas dalam penelitian ini adalah dengan menggunakan rumus Alpha. Hasil pengujian reliabilitas diringkas berikut ini.

Tabel 2. Uji Reliabilitas

\begin{tabular}{cccc}
\hline Variabel & Alpha & Batasan & Keterangan \\
\hline Kepatuhan Perpajakan & 0,721 & 0,7 & Reliabel
\end{tabular}

Sumber: Data primer diolah, 2019

Hasil tabel uji reliabilitas menunjukkan bahwa variabel kepatuhan perpajakan menunjukkan nilai Alpha yang lebih besar dari 0,7. Dengan demikian, konsep variabel kepatuhan perpajakan adalah reliabel sehingga layak digunakan sebagai alat ukur dalam pengujian statistik. 
Tabel 3. Deskripsi Responden

\begin{tabular}{llcc}
\hline & Karakteristik & Jumlah & \% \\
& & (N=100) & \\
\hline Jenis Kelamin & Laki-laki & 47 & 47 \\
Umur & Perempuan & 53 & 53 \\
& $<20$ tahun & 7 & 7 \\
& 20 tahun-30 tahun & 49 & 49 \\
& 31 tahun-40 tahun & 20 & 20 \\
& 41 tahun-50 tahun & 15 & 15 \\
& 51 tahun-60 tahun & 7 & 7 \\
Tingkat Pendidikan & $>60$ tahun & 2 & 2 \\
& SD & 2 & 2 \\
& SMP/SLTP & 1 & 1 \\
& SMA/SLTA & 39 & 39 \\
& Akademi (D3) & 8 & 8 \\
& Perguruan Tinggi (S1) & 38 & 38 \\
& Perguruan Tinggi (S2) & 9 & 9 \\
Jenis Pekerjaan & Pegawai Negeri & 18 & 18 \\
& Pegawai Swasta & 48 & 48 \\
& Wirausahawan & 12 & 12 \\
& Pensiunan & 1 & 1 \\
& Lainnya & 21 & 21 \\
& $<50$ juta rupiah & 88 & 88 \\
& 50 juta-250 juta rupiah & 11 & 11 \\
& 250 juta-500 juta rupiah & 1 & 1 \\
\hline
\end{tabular}

Sumber: Data primer diolah, 2019

Tabel 4. Tabel Chi-Square

\begin{tabular}{lcc}
\hline \multirow{2}{*}{ Variabel } & \multicolumn{2}{c}{ Uji Chi-Square } \\
\cline { 2 - 3 } & Chi-Square & Asymp. Sig \\
\hline Jenis Kelamin & 0,360 & 0,549 \\
Umur & 87,680 & 0,000 \\
Tingkat Pendidikan & 90,320 & 0,000 \\
Jenis Pekerjaan & 60,700 & 0,000 \\
Tingkat Penghasilan & 135,980 & 0,000
\end{tabular}

Sumber: Data primer diolah, 2019

Tabel Chi-Square menunjukkan bahwa jenis kelamin memiliki nilai Asymp. Sig 0,549 lebih besar dari 0,05. Sedangkan untuk variabel umur, tingkat pendidikan, status pernikahan, jenis pekerjaan, dan tingkat penghasilan memiliki nilai Asymp. Sig sebesar 0,000 kurang dari 
0,05. Jenis kelamin memiliki nilai Chi-Square sebesar 0,360, umur memiliki nilai Chi-Square sebesar 87,680, tingkat pendidikan memiliki nilai Chi-Square sebesar 90,320, jenis pekerjaan sebesar 60,700, dan tingkat penghasilan sebesar 135,980. Dari keenam faktor demografi di atas nilai Chi-Square terkecil yaitu jenis kelamin dan nilai Chi-Square terbesar adalah tingkat penghasilan. Dapat disimpulkan bahwa jenis kelamin tidak ada perbedaan terhadap kepatuhan perpajakan sedangkan tingkat penghasilan memiliki perbedaan yang paling besar terhadap kepatuhan perpajakan.

\section{Koefisien Determinasi $\left(\mathbf{r}^{2}\right)$}

Koefisien determinasi pada intinya mengukur seberapa jauh kemampuan model dalam menerangkan variasi variabel dependen.

\section{Tabel 5. Koefisien Determinasi}

\begin{tabular}{ccccc}
\hline Model & R & R Square & Adjusted R Square & Std. Error of the Estimate \\
\hline 1 & $.397^{\mathrm{a}}$ & .158 & .104 & 6.482 \\
\hline
\end{tabular}

Sumber: Data primer diolah, 2019

Berdasarkan tabel koefisien determinasi nilai adjusted $R$ square sebesar 0,104. Hal ini berarti faktor demografi memiliki distribusi sebesar 10,4\% terhadap kepatuhan perpajakan, sisanya 89,6\% dijelaskan oleh variabel lain. Jadi dalam penelitian ini faktor-faktor demografi yaitu jenis kelamin, umur, tingkat pendidikan, jenis pekerjaan, dan tingkat penghasilan memiliki distribusi terhadap kepatuhan perpajakan sebesar 10,4\%.

\section{HASIL DAN PEMBAHASAN}

\section{Pengaruh Jenis Kelamin terhadap Kepatuhan Perpajakan}

Jenis kelamin tidak berpengaruh terhadap kepatuhan perpajakan dengan ditunjukkan tidak adanya perbedaan kepatuhan perpajakan antara wajib pajak berjenis kelamin laki-laki maupun wajib pajak berjenis kelamin perempuan yang ditunjukkan dengan nilai Asymp. Sig bernilai 0,549 lebih besar dari 0,05 sehingga dapat dinyatakan H1 ditolak. Hasil ini selaras dengan penelitian yang dilakukan oleh Pasaribu dan Tjen (2015), Kasipillai dan Jabbar (2006), dan Al-Mamun et al (2014). Mereka menemukan bahwa tidak ada perbedaan kepatuhan perpajakan antara laki-laki dan perempuan. Mereka menyimpulkan bahwa hal ini disebabkan karena adanya persamaan persepsi antara laki-laki dan perempuan bahwa pajak itu penting sehingga keputusan yang diambil antara wajib pajak laki-laki dan perempuan dalam mematuhi peraturan perpajakan sama.

\section{Pengaruh Umur terhadap Kepatuhan Perpajakan}

Umur berpengaruh terhadap kepatuhan perpajakan dilihat dari adanya perbedaan jumlah antara wajib pajak yang lebih muda lebih banyak dibandingkan wajib pajak yang lebih tua yang ditunjukkan oleh nilai Asymp. Sig bernilai 0,000 kurang dari 0,05 sehingga dapat dinyatakan $\mathrm{H} 2$ diterima. Hasil penelitian menunjukkan bahwa umur berpengaruh terhadap 
kepatuhan perpajakan. Hasil penelitian ini sama dengan penelitian yang dilakukan oleh Kurniati dan Fevriera (2011) dan Al-Mamun et al (2014) yang menyatakan bahwa terjadi perbedaan antara wajib pajak yang muda dan yang tua. Mereka menyimpulkan bahwa wajib pajak yang muda lebih patuh dibandingkan dengan wajib pajak yang lebih tua. Dalam penelitian ini kelompok umur yang paling besar pengaruhnya dalam kepatuhan perpajakannya adalah pada kelompok umur 20 tahun-30 tahun sebesar $49 \%$ yang termasuk kategori muda. Penelitian ini menjelaskan bahwa jumlah wajib pajak yang berumur lebih muda sebanyak $76 \%$ dan wajib pajak yang berumur lebih tua hanya sebanyak 24\%. Hal ini disebabkan karena masyarakat pada usia muda lebih banyak terikat dengan suatu instansi pekerjaan dimana diharuskan untuk memenuhi kepatuhan perpajakannya sesuai undang-undang perpajakan yang berlaku.

\section{Pengaruh Tingkat Pendidikan terhadap Kepatuhan Perpajakan}

Tingkat pendidikan berpengaruh terhadap kepatuhan perpajakan dilihat dari adanya perbedaan jumlah wajib pajak yang berpendidikan tinggi lebih banyak dibanding yang berpendidikan rendah yang ditunjukkan oleh Asymp. Sig bernilai 0,000 lebih kecil dari 0,05 sehingga dapat dinyatakan $\mathrm{H} 3$ diterima. Penelitian ini menunjukkan bahwa wajib pajak yang berpendidikan tinggi (SMA, Akademi (D3), Sarjana (S1 dan S2) sebanyak 97\% dan wajib pajak yang berpendidikan rendah (SD dan SMP) sebanyak 3\% dari kategori tingkat pendidikan yang rendah dan tinggi kelompok tingkat pendidikan yang paling besar nilainya adalah tingkat SMA/SLTA sebesar 39\%. Hal ini dapat disimpulkan bahwa wajib pajak yang berpendidikan tinggi lebih patuh dibandingkan dengan wajib pajak yang berpendidikan lebih rendah, sehingga tingkat pendidikan mempengaruhi tingkat kepatuhan perpajakan. Hasil penelitian ini selaras dengan penelitian Kurniati dan Fevriera (2011) dan Al-Mamun et al (2014).

\section{Pengaruh Jenis Pekerjaan terhadap Kepatuhan Perpajakan}

Jenis pekerjaan berpengaruh terhadap kepatuhan perpajakan. Kepatuhan perpajakan antara wajib pajak yang memiliki jenis pekerjaan yang berbeda ditunjukkan oleh Asymp. Sig bernilai 0,000 lebih kecil dari 0,05 sehingga dapat dinyatakan H5 diterima. Hasil penelitian ini selaras dengan penelitian Pasaribu dan Tjen (2015) menyatakan bahwa terdapat perbedaan atas jenis pekerjaan wajib pajak yaitu antara wajib pajak yang bekerja sebagai pegawai negeri dan pegawai swasta dengan wirausahawan, pensiunan, dan pekerjaan lainnya. Dari kelompok jenis pekerjaan nilai yang paling besar dimiliki oleh pegawai swasta sebesar $48 \%$.

\section{Pengaruh Tingkat Penghasilan terhadap Kepatuhan Perpajakan}

Tingkat penghasilan berpengaruh terhadap kepatuhan perpajakan. Dilihat adanya perbedaan jumlah antara wajib pajak yang memiliki tingkat penghasilan rendah berbeda dengan wajib pajak yang memiliki tingkat penghasilan tinggi yang ditunjukkan oleh Asymp. Sig bernilai 0,000 lebih kecil dari 0,05 sehingga dapat dinyatakan H6 diterima. Tingkat penghasilan yang rendah akan membuat wajib pajak untuk lebih patuh dalam hal perpajakan karena dianggap wajib pajak yang berpenghasilan rendah lebih takut terkena sanksi yang 
lebih memberatkan. Dari kelompok tingkat penghasilan yang paling besar nilainya adalah wajib pajak yang tingkat penghasilannya $<50$ juta rupiah. Dapat disimpulkan bahwa tingkat penghasilan berpengaruh terhadap kepatuhan perpajakan. Hasil penelitian ini sama dengan penelitian yang dilakukan oleh Pasaribu dan Tjen (2015).

\section{KESIMPULAN DAN SARAN}

Berdasarkan hasil dari penelitian ini dan pembahasan yang telah dijelaskan maka kesimpulan yang didapatkan adalah sebagai berikut:

1. Jenis kelamin tidak berpengaruh terhadap kepatuhan perpajakan.

2. Umur, tingkat pendidikan, jenis pekerjaan, dan tingkat penghasilan berpengaruh terhadap kepatuhan perpajakan.

3. Faktor-faktor demografi yaitu jenis kelamin, umur, tingkat pendidikan, status pernikahan, jenis pekerjaan, dan tingkat penghasilan memiliki distribusi terhadap kepatuhan perpajakan sebesar $10,4 \%$.

Peneliti menyadari adanya beberapa keterbatasan yang mungkin mempengaruhi hasil penelitian ini dan bisa diperbaiki oleh peneliti selanjutnya, yaitu:

1. Enam variabel independen yang meliputi jenis kelamin, umur, tingkat pendidikan, jenis pekerjaan, dan tingkat penghasilan hanya mampu menjelaskan adjusted $R$ square sebesar $10,4 \%$, sedangkan $89,6 \%$ sisanya dijelaskan oleh variabel-variabel lain sehingga masih ada variabel-variabel yang berpengaruh namun tidak dimasukkan dalam penelitian ini.

2. Pengambilan sampel yang digunakan dalam penelitian ini adalah teknik convenience atau sampel yang dipilih dengan pertimbangan kemudahan. Beberapa kasus yang menggunakan teknik ini hasilnya ternyata kurang obyektif.

Berdasarkan keterbatasan pada penelitian ini, maka dapat diberikan beberapa saran dengan maksud untuk meningkatkan mutu penelitian selanjutnya. Untuk itu penelitian selanjutnya sebaiknya:

1. Meningkatkan $\mathrm{R}$ square dengan cara menambah variabel independen seperti etnik (AlMamun et al, 2014), sosialisasi tentang perpajakan dan sanksi pajak (Kurniati dan Fevriera, 2011).

2. Menggunakan teknik pengambilan sampel yang sering digunakan, misalnya dengan menggunakan purposive sampling yaitu pengambilan sampel dengan sengaja dan sesuai dengan kriteria sampel yang diperoleh benar-benar sesuai dengan penelitian yang dilakukan.

\section{DAFTAR PUSTAKA}

Adioetomo, S. M. \& Samosir, O. B. (2011). Dasar-dasar demografi. Jakarta: Salemba Empat.

Ajzen, I. (1991). The theory of planned behavior. Organizational Behavior and Human Decision Processes, 50(2), 179-211.

Al-Mamun, A., Entebang, H., Mansor, S. A., Yasser, Q. R., Nathan, T. M., Rahman, T. A., \& Rahman, M.A. (2014). The impact of demographic factors on tax compliance attitude 
and behavior in Malaysia. Journal of Finance, Accounting and Management, 5(1), 109-124.

Budiman, N. A. (2018). Kepatuhan pajak UMKM di Kabupaten Kudus. Profita: Komunikasi Ilmiah Akuntansi dan Perpajakan, 11(2), 21-31.

Cahyonowati, N. (2011). Model moral dan kepatuhan perpajakan: Wajib pajak orang pribadi. JAAI, 15(2), 161-177.

Halimah, N. (2012). Faktor-faktor yang mempengaruhi perilaku kepatuhan wajib pajak orang pribadi dalam pembayaran pajak penghasilan (Studi empiris WPOP di Kabupaten Pati). Skripsi Universitas Muria Kudus: Kudus.

Hungu. (2007). Demograi kesehatan Indonesia. Jakarta: Grasindo.

Kasipillai, J. \& Jabbar, H. A. (2006). Gender and ethnicity differences in tax compliance. Asian Academy of Management Journal, 11(2), 73-88.

Kurniati, A. \& Favriera, S. (2011). Analisis pengaruh sosialisasi, sanksi dan faktor-faktor demografi terhadap kepatuhan wajib pajak PBB di Surakarta. Kinerja Jurnal Bisnis dan Ekonomi, 15(2), 160-174.

Mardiasmo. (2011). Perpajakan. Yogyakarta: Andi Offset.

Mulyasana, D. (2012). Pendidikan bermutu dan berdaya saing. Bandung: PT. Remaja Rosdakarya.

Nurmantu, Safri. (2005). Pengantar perpajakan. Jakarta: PT. Granit.

Pasaribu, G. F. \& Tjen, C. (2015). Pengaruh faktor-faktor demografi terhadap kepatuhan perpajakan di Indonesia. Berkala Akuntansi dan Keuangan Indonesia, 1(2), 145-162. 
